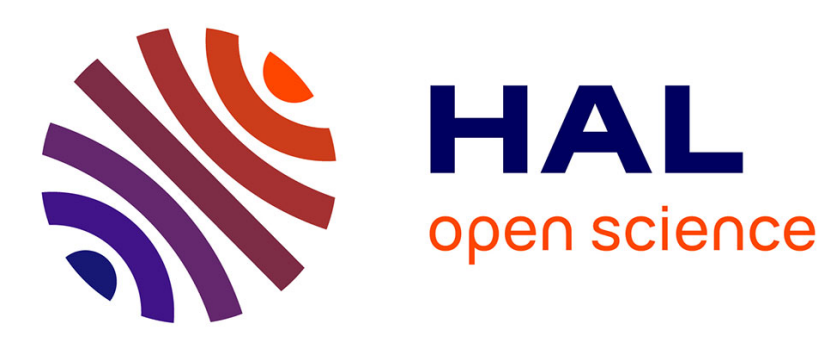

\title{
Glutamine metabolism in old age
}

Dominique Meynial-Denis

\section{To cite this version:}

Dominique Meynial-Denis. Glutamine metabolism in old age. Glutamine: Biochemistry, Physiology, and Clinical Applications, CRC Press Taylor \& Francis Group, 386 p., 2017, 9781482234299. hal02784867

\section{HAL Id: hal-02784867 \\ https://hal.inrae.fr/hal-02784867}

Submitted on 4 Jun 2020

HAL is a multi-disciplinary open access archive for the deposit and dissemination of scientific research documents, whether they are published or not. The documents may come from teaching and research institutions in France or abroad, or from public or private research centers.
L'archive ouverte pluridisciplinaire HAL, est destinée au dépôt et à la diffusion de documents scientifiques de niveau recherche, publiés ou non, émanant des établissements d'enseignement et de recherche français ou étrangers, des laboratoires publics ou privés. 


\section{Allitilnin}

Glutamine: Biochemistry, Physiology, and Clinical Applications describes the different functions of glutamine (Gin) in animals and ho beyond those of a simple metabolic fuel or protein precursor. This book has gathered together, in an unbiased and critical manner, all the available evidence and research on GIn including pathology (neurological diseases, intestinal diseases, critical illness, and cancer), physiology (successful aging), catabolic states, immunity, and exercise Specia attention is given to the potential benefit of Gln in states of insulin resistance and the role of GIn as a "conditionally essential" amino acid.

Features

- Promotes the signaling role of GIn in autophagy, which is an emerging concept in aging due to the fact that its increase can favor longevity.

Considers how a high concentration of Gln and its accumulation in plasma and in the brain can induce toxicity and lead to severe central nervous system diseases.

Demonstrates how Gin supplementation is beneficial for the recovery of intestinal mucosal integrity and for intestinal diseases and aging. warranted in the event of hypoglutaminemia and the absence of renal or hepatic failure. Highlights how GIn, as a pror

mising biomarker or even as a in cancer, could have an important role in cer strategies.

The contributors are either pioneers or experts in the area of GIn from all around the globe, including Australia, Brazil, Canada, China, Europe, and the United States. This book is a valuable source of information for nutridion scientists, medical doctors, sports scientists, food scientists, for students in these fields and will be an important addition to university libraries.

$1+1$

Кㄹуㅁ

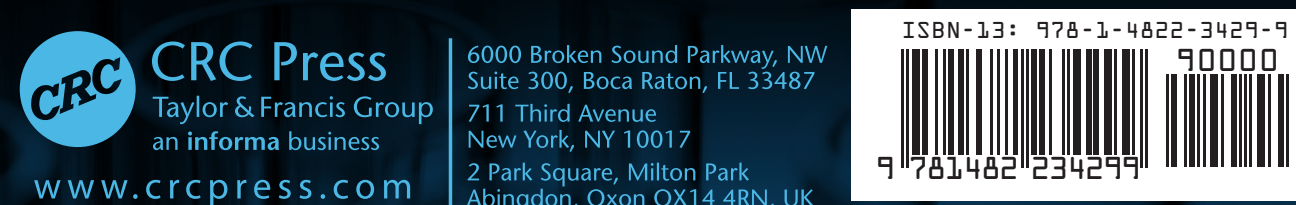

Biochemistru, Phusiologu, and Clinical Applications

$-$

r

e

$\rightarrow$

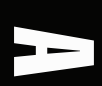

要

2

m

(B)

\section{biochemistry, Physiologu, and Clinical Applicalions}

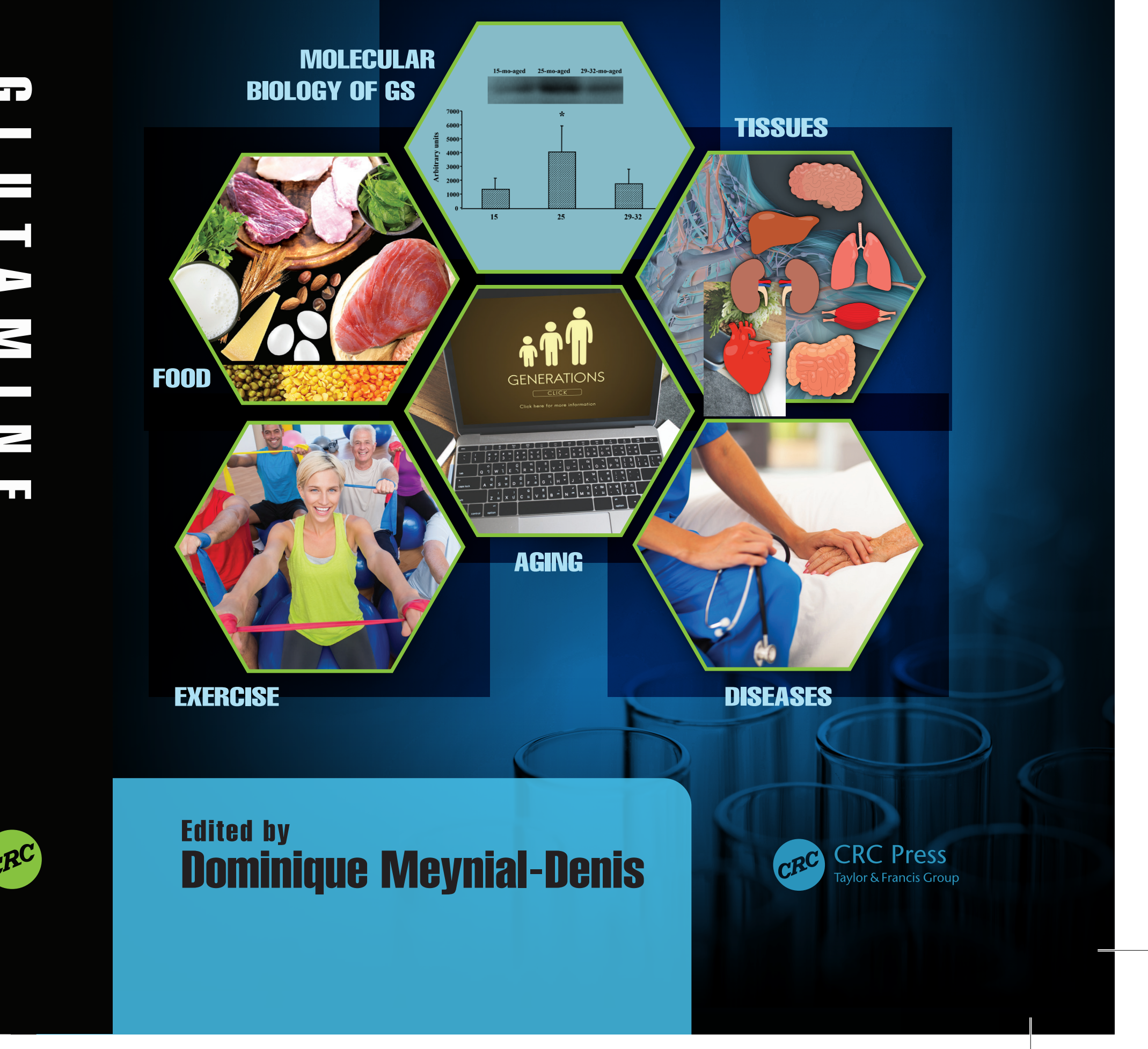

